\title{
A case report of simultaneously acute myocardial infarction and pneumonitis associated with vaping electronic cigarette
}

\section{Elektronik sigara İle İlişkili eş zamanlı akut miyokard enfarktüsü ve pnömoni olgusu sunumu}

\author{
Mohammed ABUSHAREKH' 1 , Ertugrul ERCAN ${ }^{1} \square$, Hakan GOCER ${ }^{2} \square$, Ahmet Baris DURUKAN ${ }^{3} \square$
}

${ }^{1}$ Medical Park Izmir Hospital, Department of Cardiology, Izmir/ TURKEY

${ }^{2}$ Private Edremit Korfez Hospital, Department of Cardiology, Balikesir/TURKEY

${ }^{3}$ Medigunes Hospital, Department of Cardiovascular Surgery, Manisa/TURKEY

\begin{abstract}
Electronic cigarettes (e-cigarettes) have recently been widely used as a method to conventional smoking cessation or as an alternative, especially among young population. The newly identified E-cigarette, or vaping, product use associated lung injury (EVALI) and the risk of myocardial infarction may lead to catastrophic consequences including death. Herein, we present the case of a ST-elevation myocardial infarction (STEMI) accompanied by Pneumonitis in the setting of E-cigarette use in a 37-yearold male who presented with retrosternal chest pain at rest and shortness of breath that started 2 hours before admission.
\end{abstract}

Keywords: Electronic cigarette; myocardial infarction; pneumonitis.

Öz

Elektronik sigaralar (e-sigaralar) son zamanlarda geleneksel sigara bırakma yöntemi olarak veya özellikle genç nüfus arasında alternatif olarak yaygın bir şekilde kullanılmaktadır. Yeni tanımlanan E-sigara veya vaping, ürün kullanımına bağlı akciğer hasarı (EVALI) ve miyokard enfarktüsü riski, ölüm dahil olmak üzere feci sonuçlara yol açabilir. Burada, istirahatte retrosternal göğüs ağrısı ve başlayan nefes darlığı şikayeti ile başvuran 37 yaşında bir erkekte E-sigara kullanımı durumunda Pnömoni eşliğinde ST yükselmeli miyokard infarktüsü (STEMI) olgusunu sunuyoruz.

Anahtar kelimeler: Elektronik sigara; miyokard enfarktüsü; pnomoni.

Corresponding Author*: Hakan Göçer, Private Edremit Korfez Hospital, Department of Cardiology, Balikesir/TURKEY

E-mail: hgocer@gmail.com

ORCID: 0000-0002-9644-9579

Recevied: 03.02.2021 accepted:18.05.2021

Doi: $10.18663 / \mathrm{tjcl} .873932$ 


\section{Introduction}

The use of tobacco and its products, which constitute an important risk factor for cardiovascular and pulmonary diseases, remains an important public health issue.In recent years the use of electronic cigarettes (E-cigarettes) as an alternative to smoking or for quitting it has become increasingly popular. E-cigarettes aerosolize liquid containing nicotine and tetrahydrocannibidiol (THC), cannabidiol (CBD) or other unknown frequently flavored non-nicotine substances [1]. The use of a metal platform that vaporize cannabis concentrate leads to inhalation of substances released at higher temperatures such as rust, solder and benzene [2]. Since June, 2019, 1888 cases of e-cigarette, or vaping, product use associated acute lung injury (EVALI) have been reported in the USA. 37 of them were fatal and some presented with acute respiratory failure requiring mechanical ventilation support [3]. We herein present the case of a ST-elevation myocardial infarction (STEMI) accompanied by Pneumonitis in the setting of E-cigarette use in a 37-year-old male.

\section{Case}

A 37-year-old man was referred to our emergency department complaining of retrosternal chest pain with radiation to the left arm and shortness of breath that started 2 hours before admission. His past medical history was significant for hypertension, 10 pack-years of conventional cigarette and 4-month E-cigarette vaping history. His heart rate was 97 beats per minute, blood pressure was $144 / 86 \mathrm{mmHg}$, oxygen saturation was $92 \%$ on ambient air, respiratory rate was 24 breaths per minute, and he was afebrile on admisson and during hospital stay. The 12-lead electrocardiogram revealed sinus rhythm with ST segment elevation on leads DII, DIII, aVF and $\mathrm{V} 6$ accompanying with reciprocal ST segment depression on leads V1-5. Emergency coronary angiography demonstrated total occlusion of the proximal portion of the high diagonal artery (Figure 1A). Percutaneous coronary intervention (PCI) and direct implantation of drug-eluting stent was successfully performed. TIMI 3 flow was achieved and there were no complications during the procedure (Figure 1B).

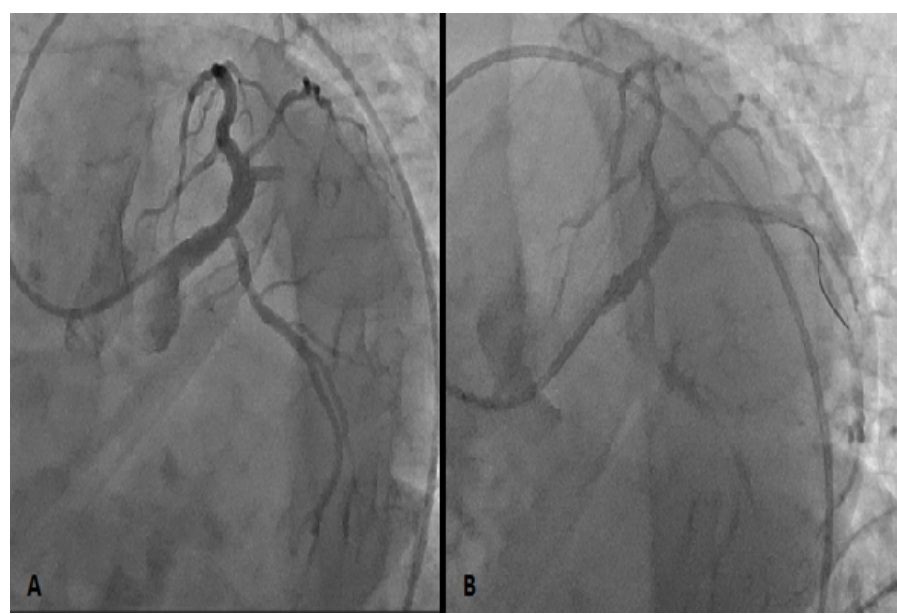

Figure 1: Coronary Angiography
Following $\mathrm{PCl}$ the patient was admitted to the CICU. Although ST-segment resolution was observed on control electrocardiography, the patient's complaints of dyspnea did not regress. Physical examination revealed scattered wheezing and crackles at bottom right middle of the lung. Immediate echocardiography was performed revealing hypokinesia in the mid-basal segment of the anterolateral wall and LV EF was found to be $50 \%$ globally. acute mechanical complications of $\mathrm{Ml}$ such as acute mitral regurgitation, ventricular septal defect or cardiac tamponade were excluded. Hypoxemia was detected in arterial blood gas and direct chest radiography was performed. Cardiomegaly, blunting of the right costophrenic sinus and infiltration erasing the diaphragmatic contour in the right lower lung zone were observed.Thorax Computed Tomography (CT) was performed for differential diagnosis and there was bilateral pleural effusion (more prominent on the right), Peribroncovascular thickening in the bilateral central lung and ground-glass infiltrates in the lower lobes of both lungs and posterior of the upper lobes bilaterally were observed (Figure 2). Complete blood cell count revealed an elevated white blood cell count of $14.5(\times 103 / \mathrm{mL})$, with 82.6 $\%$ neutrophils, $0.3 \%$ eosonphils, $9.4 \%$ lymphocytes, and $7.4 \%$ monocytes. hemoglobin level was $14.9 \mathrm{gm} / \mathrm{dL}$, with a platelet count of $262000 / \mathrm{mL}$. Erythrocyte sedimentation rate in the first hour was $48 \mathrm{~mm}$, with an elevated C-reactive protein level of $31.3 \mathrm{mg} / \mathrm{L}$. Intravenous loop diuretic was initiated in the patient who was evaluated as pulmonary edema in the foreground,Ceftriaxone and bronchodilator treatment was added in consultation with pulmonologist because the pneumonia could not be ruled out.

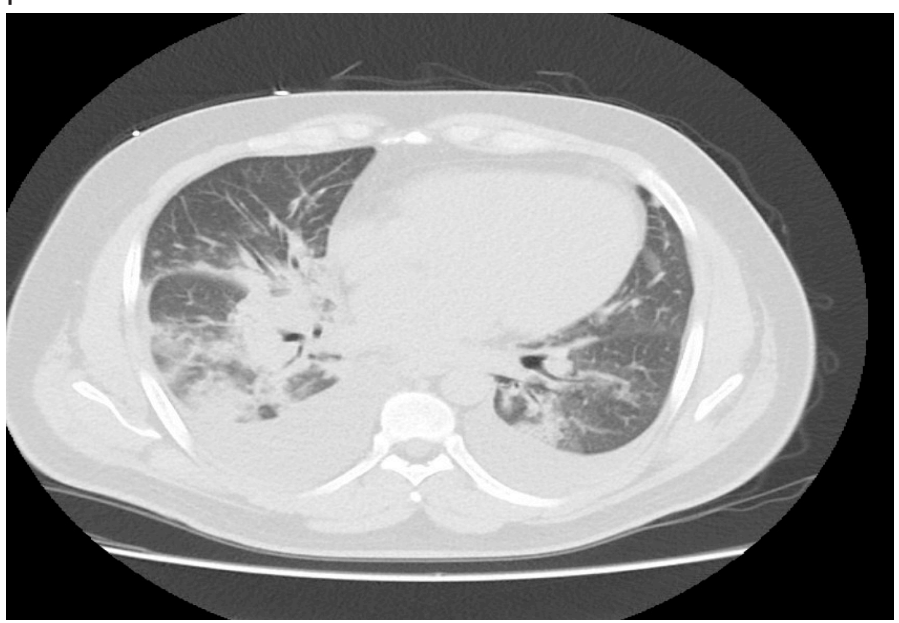

Figure 2: Thorax Computed Tomography (CT)

Although the patient was observed in a negative balance due to diuretic therapy and despite absent of acute pathology in the controlelectrocardiographyand echocardiography, the patient's 
complaints of shortness of breath not fully recovered and physical examination did not show a significant improvement in auscultation findings. Hypoxemia also ongoig and relatively following 3 days, c-reactive protein levels decreased to $7.7 \mathrm{mg} / \mathrm{L}$, hypoxemia improved, dyspnea disappeared and physical examination findings were normalized. There was no active infiltrative lesion in the lung parenchyma on the chest X-ray taken 1 week later. Bilateral cardiophrenic and costophrenic sinuses were aslo observed clear.

\section{Discussion}

The newly identified E-cigarette, or vaping, product use associated lung injury (EVALI) and the risk of myocardial infarction may lead to catastrophic consequences including death.[1] Intense inflammatory response is described to have a key role in the pathophysiological pathway in EVALI. [2,3] especially products containing $\mathrm{THC}$ oil were held responsible but do not seem to be the only ones. Diluent agents such as vitamin $E$ acetate can initiate the inflammatory cascade when heated and inhaled and consequently causes lipoid pneumonia, diffuse alveolar haemorrhage, or hypersensitivity pneumonitis.[4]

Similar to conventional cigarettes, E-cigarettes have been found independently associated with increased risk of myocardial infarction, as well as the use of both simultaneously is riskier than using either product alone.[5] In E-smokers the acute sympathomimetic effect associated with inhaled nicotine alongside increased oxidative stress and harmful effects of E-cigarettes on endothelial function increases the cardiovascular risk. [4,5] Furthermore E-vapor, by influencing the airway epithelial barrier triggers systemic inflammation, inducing thrombocyte activation, aggregation and adhesion and leading to multiorgan dysfunction and fibrosis in mice.[5] In this context we believe that hypersensitivity coronary disorder known as Kounis syndrome could be the subject in E-vaping. Mentioned syndrome can be cauesd by various stimulants such as drugs, coronary stents, cannabis and also environmental exposures. $[4,5]$ Vasospasm, myocardial infarction and stent thrombosis in the presence of thrombus infiltrated by eosinophils and/or mast cells are the reported mechanisms. The Type II variant of the syndrome occurs in consequence of plaque erosion and/or rupture induced by inflammatory response in individuals with pre-existing atherosclerosis.[5]

Although there are concerns about the risks of delayed wound healing, myocardial thinning, and rupture associated with corticosteroid use in the case of acute MI, this is usually doseand time-dependent, and most studies on this issue have been performed before the revascularization era.[5,6] On the other hand, a meta-analysis based on the important role of acute and chronic inflammation in the pathophysiology of atherosclerosis revealed a statistically insignificant decrease in mortality with corticosteroids.[6] Furthermore, uncomplicated use of corticosteroids in patients with kounis syndrome with ST- segment elevated $\mathrm{MI}$ is reported in the literature.[6]

\section{Conclusion}

Electronic cigarette or vaping has been proven to be not innocent, although it has been introduced as a method of quitting smoking. Associated lung injury such as alveolar hemorrhage and hypersensitivity pneumonitis, myocardial infarction and increased cardiovascular risk was determined. Accordingly, healthcare professionals and patients should be warned about these possible harmful effects.

* Local Ethical Committee reviewed and approved the research protocol of our study. Informed constent was obtained from parents of the patient and the principles of the Helsinki Declaration were followed.

\section{Declaration of conflict of interest}

The authors received no financial support for the research and/or authorship of this article. There is no conflict of interest

\section{References}

1. Moheimani RS, Bhetraratana M, Yin F, Peters KM, Gornbein J, Araujo JA, Middlekauff HR. Increased cardiac sympathetic activity and oxidative stress in habitual electronic cigarette users: implications for cardiovascular risk. JAMA Cardiol 2017; 2: 278-84.

2. Bhatta DN, Glantz SA.Electronic Cigarette Use and Myocardial Infarction Among Adults in the US Population Assessment of Tobacco and Health. J Am Heart Assoc 2019; 8: 12317.

3. Breitbarth AK, Morgan J, and Jones AL: E-cigarettes-an unintended illicit drug delivery system. Drug Alcohol Depend 2018; 192: 198-211.

4. Bhatta DN, Glantz SA. Electronic Cigarette Use and Myocardial Infarction Among Adults in the US Population Assessment of Tobacco and Health. J Am Heart Assoc 2019; 8: 12317.

5. Moheimani RS, Bhetraratana $M$, Peters KM, Yang BK, Yin F, Gornbein J, Araujo JA, Middlekauff HR. Sympathomimetic effects of acute e-cigarette use: role of nicotine and non-nicotine constituents. J Am Heart Assoc 2017; 6: 6579.

6. Hom S, Chen L, Wang T, Ghebrehiwet B, Yin W, Rubenstein DA. Platelet activation, adhesion, inflammation, and aggregation potential are altered in the presence of electronic cigarette extracts of variable nicotine concentrations. Platelets 2016; 27: 694-702. 